\title{
Organophosphorus Insecticides and Glucose Homeostasis
}

\author{
Apurva Kumar R. Joshi and P.S. Rajini \\ Food Protectants and Infestation Control Department, Central Food Technological \\ Research Institute (CSIR lab), Mysore, \\ India
}

\section{Introduction}

The modern world has heavily thrived on the revolution in agricultural practices that have culminated in tremendous boost in agricultural productivity. Pesticides are perhaps one of the most important and effective strategies of the green revolution. Pesticides are the only class of toxic substances that are intentionally released into the environment for achieving greater good, a decision that far outweighs their toxicological concerns. Organophosphorus insecticides (OPI) are one of the most extensively used classes of insecticides. Chemically they are derivatives of phosphoric $\left(\mathrm{H}_{3} \mathrm{PO}_{4}\right)$, phosphorous $\left(\mathrm{H}_{3} \mathrm{PO}_{3}\right)$ or phosphinic acid $\left(\mathrm{H}_{3} \mathrm{PO}_{2}\right)$ (Abou-Donia, 2003). The OPI were initially introduced as replacements for the much persistent organochlorine insecticides (Galloway \& Handy, 2003). With systemic, contact and fumigant action, OPI find use as pest control agents in various situations. OPI are extensively used in agricultural practices for protecting food and commercial crops from various types of insects. In addition, OPI are also used in household situations for mitigating menacing pest varieties. They are not very stable chemically or biochemically and are degraded in soil, sediments and in surface water. Perhaps, it is this instability of these agents that has lead to their widespread and indiscriminate use, which has exposed animal and human life to various forms of health hazard. The increase in their use has lead to wide range of ecotoxicological problems and exposure to OPI is believed to be major cause of morbidity and mortality in many countries.

Huge scientific body of evidence suggests that OPI exposure is a major toxicological threat that may affect human and animal health because of their various toxicities such as neurotoxicity, endocrine toxicity, immunotoxicity, reproductive toxicity, genotoxicity and ability to induce organ damage, alterations in cellular oxidative balance and disrupt glucose homeostasis. Indeed, the data on residue levels of OPI in various sources reported from India does create a huge cause for concern regarding their toxic effects. Samples of raw and bottled water were reported to be contaminated with various OPI residues, some of which were much higher than recommended levels (Mathur et al., 2003). Sanghi et al. (2003) have reported OPI residue levels in breast milk samples in India. Based on the levels of OPI residues, it has been speculated that infants may consume 4.1 times higher levels of malathion than the average daily intake levels recommended by the World Health Organisation. Similarly, human blood samples were reported to be contaminated with residues of monocrotophos, chlorpyrifos, malathion and phosphamidon (Mathur et al., 
2005). Thus, OPI present a realistic environmental threat that could affect various facets of human health.

\section{Toxicity of organophosphorus insecticides}

The toxicity of active OPI is attributed to their ability to inhibit acetylcholinesterase (AChE, choline hydrolase, EC 3.1.1.7), an enzyme that catalyses the hydrolysis of the neurotransmitter acetylcholine (ACh), leading to cholinergic stress as a result of stimulation of muscarinic and nicotinic ACh receptors (Fukuto, 1990; Sogorb \& Vilanova, 2003; AbouDonia, 2003). The inhibition of AChE by an OPI takes place via a chemical reaction in which the serine hydroxyl moiety (of the active site) is phosphorylated. The phosphorylated enzyme is highly stable and, depending on the groups attached to the central ' $\mathrm{P}$ ' atom of the OPI molecule, may be irreversibly inhibited.

There are several factors that determine the toxicity of OPI. Important of these are route and levels of exposure, structure of the substance and its interaction with the biotransformation/detoxification system of the body. The metabolic fate of OPI is basically the same in insects and animals. Following absorption, the distribution of OPI is variable. Blood half-lives are usually short, although plasma levels are in some cases maintained for several days. OPI undergo extensive biotransformation, which is complex and involves several metabolic systems in different organs, with simultaneous oxidative biotransformation at a number of points in the molecule, utilizing the cytochrome P-450 isoenzyme system. Metabolism occurs principally by oxidation, hydrolysis by esterases, and by transfer of portions of the molecule to glutathione. Oxidation of OPI may result in more or less toxic products. Most mammals have more efficient hydrolytic enzymes than insects and, therefore, are often more efficient in their detoxification processes. Numerous conjugation reactions follow the primary metabolic processes, and elimination of the phosphorus-containing residue may be via the urine or faeces. Some bound residues remain in exposed animals. Binding seems to be to proteins, principally, since there are limited data showing that incorporation of residues into DNA (Eto, 1974).

\subsection{Neurotoxicity}

Based on structure-function relationships, OPI are essentially neurotoxicants. Most important of their neurotoxicities is their 'cholinergic toxicity', which is a consequence of acetylcholinesterase (AChE) inhibition by OPI leading to accumulation of ACh and cholinergic stress. Signs of cholinergic toxicity include miosis, muscle fasciculation, excessive glandular secretions, nausea and vomiting (Namba, 1971). In addition, OPI are known to exert two other forms of neurotoxicities- Organophosphorus ester-induced delayed neurotoxicity (OPIDN) and Organophosphorus ester-induced chronic neurotoxicity (OPICN). OPIDN is a neurodegenerative disorder characterized by delayed onset of prolonged ataxia and upper motor neuron spasticity as a result of single or multiple exposures. OPICN refers to other forms of neurotoxicity that is distinct from both cholinergic toxicity and OPIDN. OPICN is characterized by neuronal degeneration and subsequent neurobehavioral and neuropsychological consequences (Abou-Donia, 2003).

\subsection{Oxidative stress}

Numerous studies provide evidence for the propensity of OPI to disrupt oxidative balance leading to oxidative stress (Soltaninejad \& Abdollahi, 2009). Increased lipid peroxidation, 
protein carbonylation, depletion of cellular antioxidant pools and alterations in enzymatic antioxidant status appear to be chief mechanisms of OPI-induced oxidative stress that often results in pathophysiological changes and organ damage. Several studies have demonstrated usefulness of antioxidant intervention in alleviating oxidative stress and pathophysiological changes induced by OPI (Kamath et al., 2008, Soltaninejad \& Abdollahi, 2009). These studies lend unequivocal support to view that oxidative stress mediates as one of the chief mechanisms of OPI toxicity.

\section{Organophosphorus insecticides and glucose homeostasis: mechanistic insights}

In addition to neurotoxicity and oxidative stress, alterations in glucose homeostasis often culminating hyperglycemia is increasingly being reported as characteristic outcome of OPI toxicity. Meller et al., (1981) have described two cases of human subjects who were hospitalized with many complications including hyperglycemia. With no pseudocholinesterase detected, patients were given pralidoxime (AChE activator), which improved their condition and normalized hyperglycemia. Investigations revealed that they may have been exposed to malathion sprayed in their area. This case presents a classic case of hyperglycemic outcome following exposure to OPI as patients also exhibited miosis and muscle twitching. Numerous experiments have been conducted with experimental animals that reveal hyperglycemia as a characteristic outcome of OPI poisoning. A recent review by Rahimi \& Abdollahi (2007) provides an exhaustive account of investigations revealing hyperglycemia in cases of OPI exposure.

There are certain characteristic features of alterations induced by OPI in glucose homeostasis. In cases of exposure to single dose of OPI, hyperglycemia appears to set in rapidly and peak changes are often followed by a trend of normalization. High dose of diazinon has been reported to cause hyperglycemia in mice that follows a trend of normalization (Seifert, 2001). Acute exposure of rats to malathion resulted in hyperglycemia with peak increase occurring at $2.2 \mathrm{~h}$ after administration followed by decrease after 4 h (Rodrigues et al., 1986). A similar case of reversible hyperglycemia has been reported by Lasram et al., (2008) following administration of a single dose of malathion to rats.

Biochemical changes associated with hyperglycemia serve as useful tools to understand etiology of OPI-induced hyperglycemia. Malathion has been reported to cause hyperglycemia in fasted rats. Interestingly, these hyperglycemic responses were not associated with hepatic glycogen depletion. The reversible phase of hyperglycemia was associated with increased glycogen deposition in liver, indicating that glucose may have come from gluconeogenesis (Gupta, 1974). Malathion induced hyperglycemia was associated with AChE inhibition in pancreas. More importantly, the trend of reversibility coincided with spontaneous reactivation of inhibited AChE (Lasram et al., 2008), indicating involvement of AChE-inhibition in hyperglycemia. Increase in blood glucose induced by sub chronic exposure of rats to malathion has been reported to be associated with increased glycogen phosphorylase and phosphoenolpyruvate carboxykinase activities, indicating involvement of both glycogenolytic and gluconeogenic processes. Increase in blood glucose levels induced by sub chronic exposure of rats to acephate has been reported to be associated with decrease in hepatic glycogen content (Deotare \& Chakrabarti, 1981). 


\subsection{Pancreatic dysfunctions}

Acute pancreatitis is also a well known complication of OP poisoning (Dressel et al., 1979; Frick et al., 1987; Hsiao et al., 1996), and epidemiological findings indicate that the incidence of pancreatitis is high in OPI intoxication based on various pathophysiological reports (Gokalp et al., 2005). The precise mechanisms underlying OPI-induced pancreatitis are still undefined, although it is believed to involve obstruction of pancreatic ducts and /or enhanced reactive oxygen species (Dressel et al., 1982; Sevillano et al., 2003, Sultatos, 1994). Involvement of oxidative stress following acute exposure to OPI has been reported recently (Banerjee et al., 2001) and it has been demonstrated unequivocally that lipid peroxidation is one of the molecular mechanisms involved in OPI-induced cytotoxicity (Akhgari et al., 2003; Ranjbar et al., 2002; Abdollahi et al., 2004b).

In view of the above, we attempted to understand the potential of repeated oral doses of dimethoate (DM) (at 20 and $40 \mathrm{mg} / \mathrm{kg}$ b.w/d for 30days; doses corresponding to $1 / 20$ and $1 / 10$ LD50 values) to cause alterations in glucose homeostasis and the associated biochemical alterations in pancreas of rats. We observed distinct signs of glucose intolerance among rats administered DM (Fig. 1) at time points at which un-treated rats showed normal glucose tolerance after an oral glucose load $(3 \mathrm{~g} / \mathrm{kg}$ b.w.). We also observed that DM at both doses caused significant increase in blood glucose levels with concomitant inhibition of acetylcholinesterase activity and depletion of reduced glutathione contents in pancreas (Table 1) (Kamath \& Rajini, 2007).

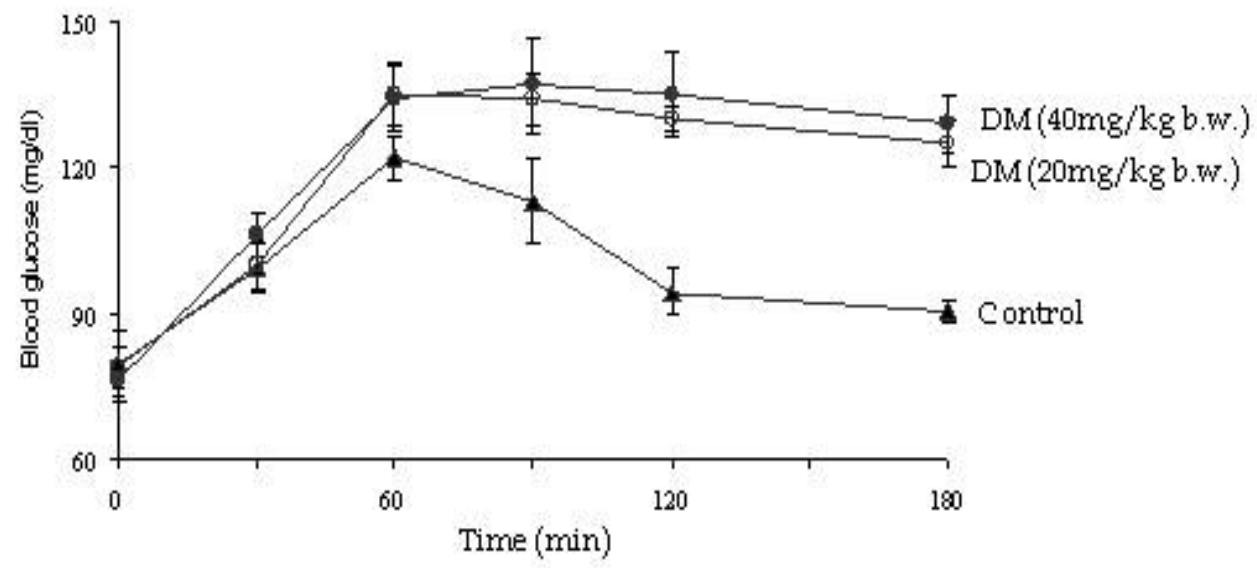

Fig. 1. Oral glucose tolerance at the end of 30 days in control (CTR) and Dimethoate (DM) treated rats. 


\begin{tabular}{|c|c|c|c|c|}
\hline Treatment & \multicolumn{2}{|c|}{ Blood glucose $(\mathrm{mg} / \mathrm{dl})$} & \multirow{2}{*}{$\begin{array}{c}\text { AChE } \\
\text { (nmoles substrate } \\
\text { hydrolyzed } / \mathrm{min} / \mathrm{mg} \\
\text { protein) }\end{array}$} & \multirow{2}{*}{$\begin{array}{c}\text { GSH } \\
\text { (mg/g tissue) }\end{array}$} \\
\hline $\begin{array}{l}\text { Dimethoate } \\
\text { (mg/kg b.w.) }\end{array}$ & Initial & Final & & \\
\hline 0 & $85.33 \pm 3.85$ & $91.33 \pm 2.41$ & $4.96 \pm 1.47$ & $1.11 \pm 0.02$ \\
\hline 20 & $87.34 \pm 5.23$ & $105.28 \pm 3.57 \mathrm{a}$ & $2.94 \pm 1.75$ & $0.99 \pm 0.05^{\mathrm{a}}$ \\
\hline 40 & $85.00 \pm 5.30$ & $138.67 \pm 5.70, b$ & $0.43 \pm 0.21^{\mathrm{a}, \mathrm{b}}$ & $0.91 \pm 0.07 \mathrm{a}, \mathrm{b}$ \\
\hline
\end{tabular}

Values are mean \pm SEM $(n=6)$;

a Comparison of control and other groups;

b Comparison of DM (20mg / $\mathrm{kg}$ b.w.) group with DM (40 mg/ $\mathrm{kg}$ b.w.) group

Table 1. Blood glucose, acetylcholinesterase (AChE) and reduced glutathione (GSH) levels in pancreas of rats administered oral doses of Dimethoate (DM) for 30 days.

Further, DM also caused significant pancreatic damage as reflected by increased amylase (23 folds) and lipase (20\&38\%) activities in serum (Fig 2). These changes were sharply paralleled by significant damage in pancreatic milieu. There was a dose-related elevation in ROS levels in pancreas of treated rats. While the increase at the lower dose was $66 \%$, a dramatic $(150 \%)$ increase was evident at the higher dose. Concomitantly, a dose-related increase in TBARS (lipid peroxidation index) levels was observed in the pancreas of DM treated rats. There was 2.5 and 3.7 fold increase in TBARS level at lower and higher doses of DM respectively (Fig. 3). Activities of selected antioxidant enzymes were significantly elevated in the pancreas of treated rats compared to that of control rats. (Table 2) (Kamath \& Rajini, 2007). These results are in accordance with the study of Hagar et al., (2002) who had earlier reported increased blood glucose levels and hyerinsulinemia with concomitant histochemical and ultramicrostructural changes in pancreas of rats following chronic exposure to dimethoate.
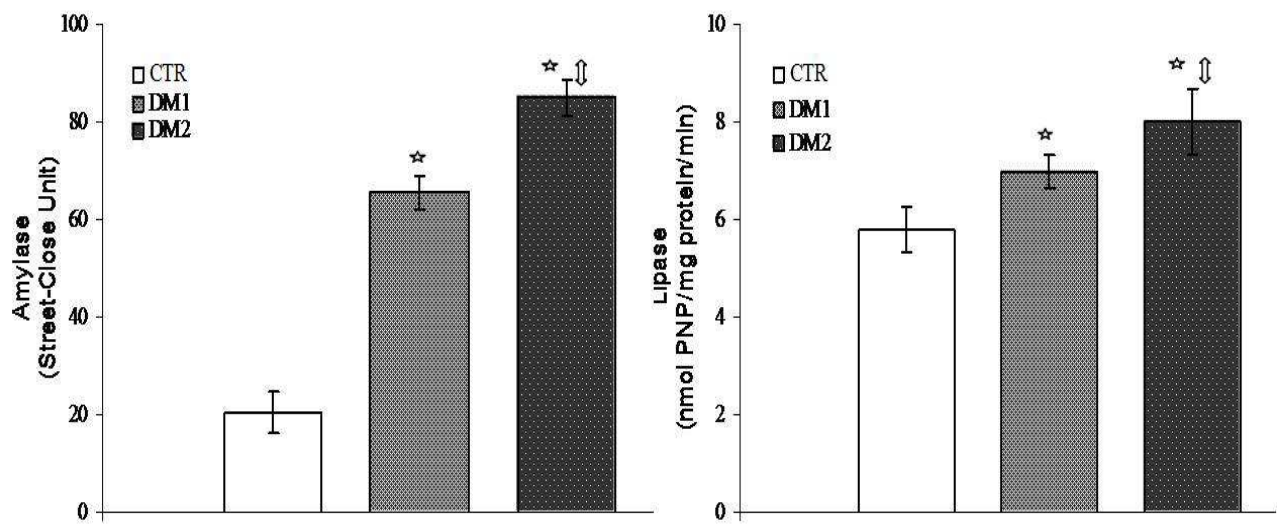

Fig. 2. Changes in pancreatic damage markers in rats induced by Dimethoate after 30 days (DM1: $20 \mathrm{mg} / \mathrm{kg}$ b.w/d; DM2: $40 \mathrm{mg} / \mathrm{kg}$ b.w/d). Values are mean \pm SEM $(\mathrm{n}=6)$; * Comparison of control and other groups $(P<0.01)$, II Comparison of DM1 with DM2 $(P<$ $0.01)$ 

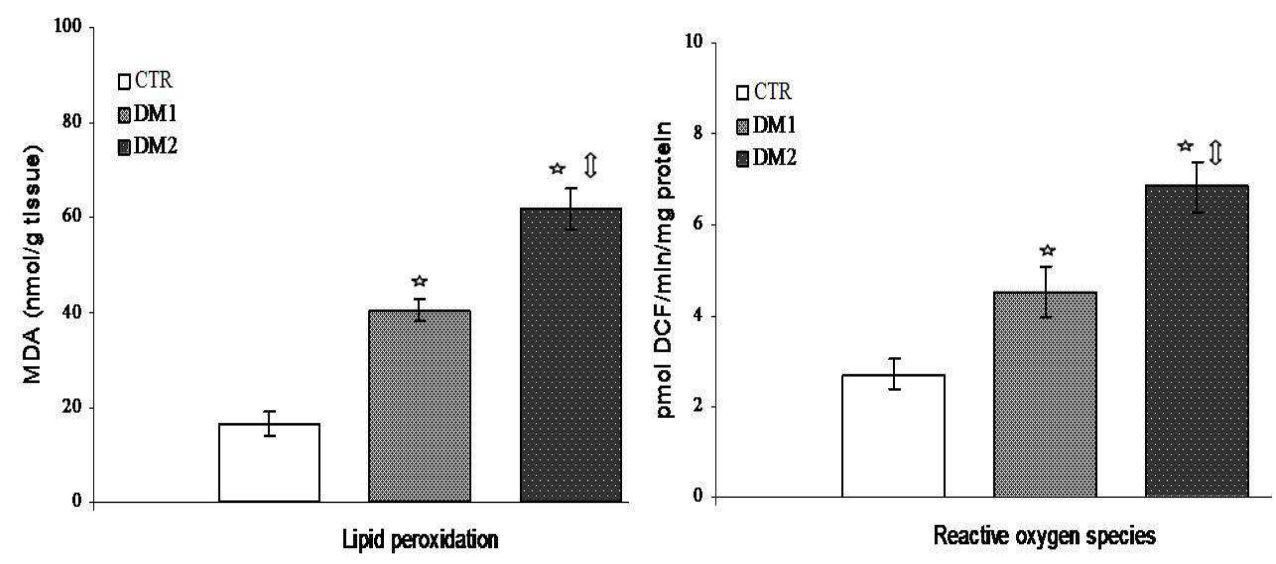

Fig. 3. Extent of lipid peroxidation and ROS levels in pancreas of control (CTR) and Dimethoate treated rats (DM1: $20 \mathrm{mg} / \mathrm{kg}$ b.w/d; DM2: $40 \mathrm{mg} / \mathrm{kg}$ b.w $/ \mathrm{d}$ ). Values are mean \pm SEM $(n=6) ;{ }^{*}$ Comparison of control and other groups $(P<0.01)$, II Comparison of DM1 with DM2 $(P<0.01)$.

Several studies have demonstrated pancreatitis after exposure to OPI (Dressel et al., 1979; Moore \& James, 1988; Hsiao et al., 1996). Increase in the serum lipase and amylase activities reported by us clearly indicates that DM results in a state of pancreatic damage. Increased serum lipase activity has also been reported after administration of methidathion, an OPI (Mollaoglu et al., 2003). These results agree with earlier reports of acute pancreatitis in humans after accidental cutaneous exposure to DM (Marsh et al., 1988) and increase in amylase activity reported in dogs after diazinon administration (Dressel et al., 1982). Together, these studies clearly indicate that OPI possess propensity to elicit structural and functional alterations in pancreatic milieu that may be associated with disruptions in euglycemic conditions. From these studies, it may be argued that OPI may present a great threat to pancreatic functions in human beings and such threats may have far-reaching consequences on gluco-regulation in human beings.

\begin{tabular}{cccccc}
\hline \multirow{2}{*}{ Group } & \multicolumn{5}{c}{ Enzyme Activity } \\
\cline { 2 - 6 } & SOD $^{1}$ & CAT $^{2}$ & GPX $^{3}$ & GR $^{3}$ & GST $^{4}$ \\
\hline CTR & $26.42 \pm 2.2$ & $9.38 \pm 0.31$ & $27.18 \pm 5.24$ & $17.50 \pm 1.60$ & $0.03 \pm 0.004$ \\
DM1 & $42.72 \pm 0.38^{\mathrm{a}}$ & $10.24 \pm 0.32$ & $25.23 \pm 3.89$ & $19.72 \pm 2.03$ & $0.04 \pm 0.003^{\mathrm{a}}$ \\
DM2 & $56.23 \pm 1.18^{\mathrm{a}, \mathrm{b}}$ & $15.44 \pm 0.51^{\mathrm{a}, \mathrm{b}}$ & $13.85 \pm 2.20^{\mathrm{a} . \mathrm{b}}$ & $25.30 \pm 1.30^{\mathrm{a}, \mathrm{b}}$ & $0.06 \pm 0.003^{\mathrm{a}, \mathrm{b}}$ \\
\hline
\end{tabular}

${ }^{1}$ units $/ \mathrm{mg}$ protein; ${ }^{2} \mu \mathrm{mol} / \mathrm{min} / \mathrm{mg}$ protein; ${ }^{3} \mathrm{nmol} / \mathrm{min} / \mathrm{mg}$ protein; ${ }^{4} \mu \mathrm{mol} / \mathrm{min} / \mathrm{mg}$ protein

Values are mean \pm SEM $(n=6)$

a Comparison of control (CTR) and other groups;

b Comparison of DM1 (DM: 20mg / kg b.w/d) group with DM2 (DM: 40 mg/kg b.w/d) group

Table 2. Antioxidant enzyme activities in pancreas of rats administered oral doses of Dimethoate for 30 days. 


\subsection{Adrenal involvement}

Studies undertaken by several researchers to investigate the mechanisms mediating hyperglycemic effects of OPI have mainly focused on the involvement of cholinergic stress and adrenal functions. We have extensively studied the mechanistic involvement of adrenals in glucotoxicity of OPI in rats mainly under acute and short-term exposure regimes. The rationale for studying adrenal involvement emerged from the typical hyperglycemic behaviour of single dose (oral) of two OPI-acephate and monocrotophos. Single dose of acephate and monocrotophos elicited rapid and transient hyperglycemia after administration. Both OPI were administered to overnight-fasted rats at 1/10 doses of their $\mathrm{LD}_{50}$ (LD50; acephate-1400mg/kg b.w., monocrotophos-18mg/kg b.w.). As depicted in Fig. 4 , both acephate and monocrotophos induced reversible hyperglycemia with peak occurring at $2 \mathrm{~h}$ after exposure. Acephate induced peak hyperglycemia at $2 \mathrm{~h}(87 \%)$, which tended to normalize thereafter and attained near-control values at $8 \mathrm{~h}$ after administration (Joshi \& Rajini, 2009). Similarly, monocrotophos also induced rapid hyperglycemia with peak occurring at $2 \mathrm{~h}(103 \%)$. Interestingly, monocrotophos induced hyperglycemia exhibited steep reversibility compared to acephate, with normalization occurring at $6 \mathrm{~h}$ (Joshi \& Rajini, 2010). This trend observed in the present study is consistent with other reports, which demonstrated reversible hyperglycemia in experimental animals following OPI administration. While Malathion has been reported to cause reversible hyperglycemia in rats (Gupta, 1974; Rodrigues et al., 1986; Seifert, 2001; Lasram et al., 2008), acute exposure to diazinon induced reversible hyperglycemia in mice (Seifert, 2001).

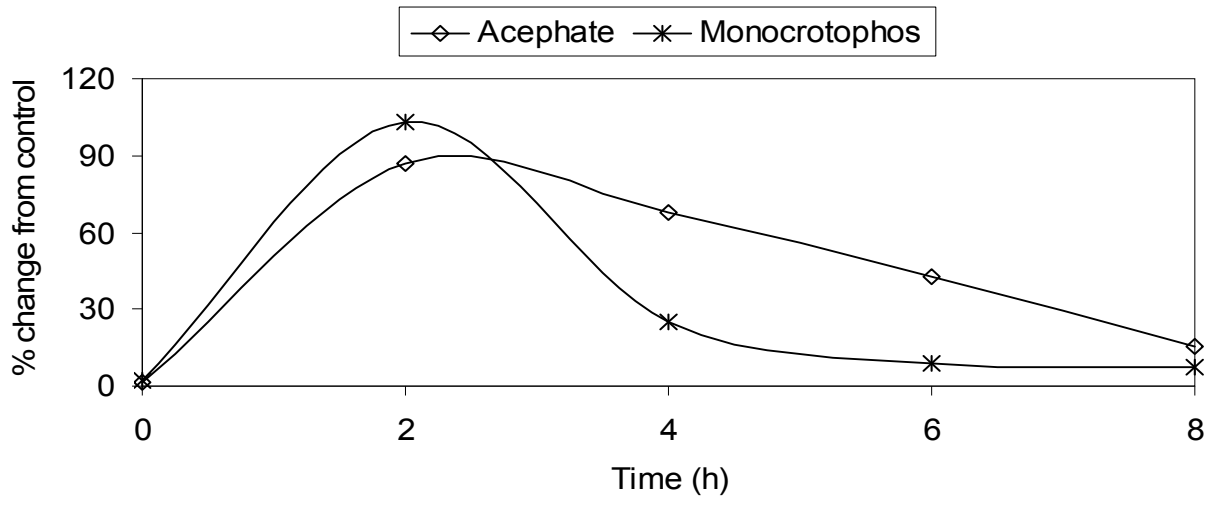

Fig. 4. Time-course of blood glucose levels in rats administered a single oral dose of acephate (140mg/kg b.w.) and monocrotophos (1.8mg/kg b.w.).

Based on the above results, we reasoned that the reversible hyperglycemia could be triggered by transient changes in the hormonal milieu of glucose homeostasis. Adrenals are an important part of the endocrine system and play a key role in glucose homeostasis by secreting glucocorticoid and amine hormones. Glucocorticoid hormones (GCs) (mainly cortisol in man and corticosterone in rodents) are secreted by the adrenal cortex under the control of hypothalamic-pituitary-adrenal axis. Glucocorticoid hormones, along with other key hormones, act to maintain blood glucose levels within narrow limits (Andrews \& Walker, 1999). GCs, glucagon and epinephrine raise blood glucose by inhibiting glucose 
uptake in the periphery and stimulating hepatic glucose release. Hepatic gluconeogenesis serves as the main source of hepatic glucose production during state of prolonged fasting and contributes significantly to development of diabetes mellitus (Pilkis \& Granner, 1992). GCs facilitate gluconeogenesis as they exert permissive effect on the process by transcriptional activation of key enzymes of gluconeogenesis viz., glucose-6-phosphatase (G6Pase) (Argaud et al., 1996), phosphoenolpyruvate carboxykinase (PEPCK) (O'Brien et al., 1990) and tyrosine aminotransferase (TAT) (Ganss et al., 1994). Increased glycogenolysis and gluconeogenesis appear to be the two chief mechanisms underlying OPI-induced hyperglycemia. Fenitrothion-induced increase in blood glucose in S. mossambicus was associated with decreased hepatic glycogen (Koundinya \& Ramamuthi, 1979) and sub chronic exposure of rats to acephate, which caused slight increase in blood glucose also caused depletion of liver glycogen in rats (Deotare \& Chakrabarthi, 1981). Abdollahi et al. (2004a) reported increased activity of GP and phosphoenolpyruvate carboxykinase (PEPCK) following sub chronic exposure to Malathion. Acute exposure to diazinon has been shown to cause depletion of liver glycogen with increased activity of glycogen phosphorylase, and also increased activities of gluconeogenesis enzymes in liver (Matin et al., 1989). Valexon is reported to have increased the activity of G6Pase in liver of rats (Kuz'minskaia et al., 1978). OPI and other AChE inhibiting organophosphate compounds exert strong influences on functioning of hypothalamic-pituitary-adrenal (HPA) axis, leading to increased circulating levels of corticosteroid hormones in vivo. This is particularly true in the case of acute exposure to AChE inhibiting compounds. Studies have shown elevated corticosteroid hormones levels in response to AChE-inhibiting compounds and role of AChE inhibition in the phenomenon. Single dose of Chlorfenvinphos, acephate and methamidophos have been demonstrated to elevate circulating levels of corticosterone and aldostserone after administration of a single dose (Osicka-Kaprowska et al., 1984; Spassova et al., 2000). Soman has been reported to increase plasma corticosterone levels in rodent models (Hudon \& Clement, 1986; Fletcher et al., 1998). More importantly, the stressogenic potential (hypercorticosteronemia and induction of liver tyrosine aminotransferase activity) of soman was effectively abrogated by reactivators of inhibited acetylcholinesterase (Kassa, 1995 \& 1997). Similarly, stressogenic potential of Cyclohexylmethyl phosphonofluoridate (AChE inhibitor) has been reported to be eliminated by HI-6 (AChE reactivator) (Kassa \& Bajgar, 1995). Thus, it is clearly evident that AChE-inhibiting OPI elicit hyper stimulation of adrenal functions, leading to induction of gluconeogenesis enzymes in liver.

Based on the time-course of reversible hyperglycemia induced by acephate and monocrotophos, further experiments were carried out to investigate the adrenal effects of OPI and its role in the ensuing hyperglycemia. We assessed the effects of 2 or $6 \mathrm{~h}$ exposure to either acephate (oral) or 2 or 4 h exposure to monocrotophos (oral) on plasma corticosterone, adrenal cholesterol, blood glucose, key liver gluconeogenesis enzymes (G6Pase and TAT) and hepatic glycogen content in rats. Interestingly, we observed that both acephate and monocrotophos induced strong hypercorticosteronemia with concomitant hyperglycemia and induction of liver gluconeogenesis enzyme activities. Further, hypercorticosteronemia was associated with decrease in adrenal cholesterol pools (effect of monocrotophos on adrenal pools described in the section on 'comparison between single and repeated dose effects'), which is the precursor for corticosterone synthesis (Table $3 \& 4$ ). Depletion in adrenal cholesterol pools may therefore be attributable to increased synthesis and secretion of corticosterone. Interestingly, both OPI did not cause depletion in hepatic glycogen content. At time points that represented normalization of blood glucose levels, there was 
phenomenal increase in liver glycogen levels. The data presented above clearly demonstrates co-existence of hypercorticosteronemia and induction of liver gluconeogenesis enzyme activities with hyperglycemia in OPI treated rats, indicating that OPI may trigger induction of liver gluconeogenesis machinery as result of hypercorticosteronemia, leading to hyperglycemia.

\begin{tabular}{|c|c|c|c|}
\hline & \multicolumn{3}{|c|}{ At time interval after administration } \\
\hline & $\mathrm{Oh}$ & $2 \mathrm{~h}$ & $6 \mathrm{~h}$ \\
\hline Plasma corticosterone * & $30.9 \pm 3.4^{a}$ & $55.0 \pm 2.5^{b}$ & $44.0 \pm 2.7 \mathrm{~b}$ \\
\hline Adrenal cholesterol ${ }^{* *}$ & $26.5 \pm 1.4^{\mathrm{a}}$ & $15.6 \pm 0.56^{\mathrm{b}}$ & $12.5 \pm 0.47 \mathrm{~b}$ \\
\hline Blood glucose $* * *$ & $101.6 \pm 4.6^{\mathrm{a}}$ & $182.4 \pm 5.2^{\mathrm{b}}$ & $142.7 \pm 5.2^{c}$ \\
\hline Liver G6Pase $\#$ & $90.14 \pm 4.38^{\mathrm{a}}$ & $171.93 \pm 5.61^{\mathrm{b}}$ & $112.84 \pm 4.18^{c}$ \\
\hline Liver TAT \#\# & $14.28 \pm 1.34^{\mathrm{a}}$ & $26.31 \pm 0.87 \mathrm{~b}$ & $23.7 \pm 0.48^{\mathrm{b}}$ \\
\hline Hepatic glycogen $\$$ & $316.2 \pm 34.90^{a}$ & $325.3 \pm 29.12^{\mathrm{a}}$ & $1145.0 \pm 27.92^{\mathrm{b}}$ \\
\hline \multicolumn{4}{|c|}{ (Joshi and Rajini, 2009) } \\
\hline $\begin{array}{l}\text { Data analyzed by ANOVA followe } \\
{ }^{*} \mu \mathrm{g} / \mathrm{dl} ;{ }^{* *} \mathrm{mg} / \mathrm{g} \text { tissue; }{ }^{* * *} \mathrm{mg} / \mathrm{dl} \\
\text { \# glucose- } 6 \text {-phosphatase }(\mathrm{nmol} / \mathrm{m} \\
\text { \#\# tyrosine aminotranferase }(\mathrm{nmo}\end{array}$ & $\begin{array}{l}\text { pey Test }(n=6) \\
\text { protein); } \\
\text { mg protein); } \$ \mu\end{array}$ & sue & \\
\hline
\end{tabular}

Table 3. Biochemical effects of acephate $(140 \mathrm{mg} / \mathrm{kg}$ b.w.) in rats

\begin{tabular}{cccc}
\hline & \multicolumn{3}{c}{ At time interval after administration } \\
\cline { 2 - 4 } & $0 \mathrm{~h}$ & $2 \mathrm{~h}$ & $4 \mathrm{~h}$ \\
\hline Plasma corticosterone * $^{*}$ & $36.62 \pm 1.2^{\mathrm{a}}$ & $73.82 \pm 3.8^{\mathrm{b}}$ & $45.65 \pm 1.8^{\mathrm{a}}$ \\
Blood glucose ** & $95.2 \pm 1.8^{\mathrm{a}}$ & $194.8 \pm 3.7^{\mathrm{b}}$ & $121.3 \pm 1.9^{\mathrm{c}}$ \\
Liver TAT \# $^{\#}$ & $15.86 \pm 0.8^{\mathrm{a}}$ & $32.27 \pm 1.2^{\mathrm{b}}$ & $26.87 \pm 1.8^{\mathrm{c}}$ \\
Hepatic glycogen \#\# & $213.8 \pm 49.2^{\mathrm{a}}$ & $216.4 \pm 21.1^{\mathrm{a}}$ & $925.7 \pm 27.6^{\mathrm{b}}$ \\
\hline & (Joshi and Rajini, 2010)
\end{tabular}

Data analyzed by ANOVA followed by Tukey Test $(n=6)$

${ }^{*} \mu \mathrm{g} / \mathrm{dl} ;{ }^{* *} \mathrm{mg} / \mathrm{g}$ tissue ; \# tyrosine aminotranferase ( $\mathrm{nmol} / \mathrm{min} / \mathrm{mg}$ protein); \#\# $\mu \mathrm{g} / \mathrm{g}$ tissue

Table 4. Biochemical effects of monocrotophos (1.8mg/ kg b.w.) in rats

Indeed, role of adrenals in glucotoxicity of OPI has been explored earlier. Matin et al., (1989) earlier demonstrated that single dose diazinon (OPI) caused hyperglycemia and induction of liver gluconeogenesis enzymes in normal rats while these changes did not manifest in adrenalectomized rats, indicating the involvement of adrenals in the glucotoxicity of diazinon. Our attempts to study the adrenal and glycemic effects of acephate and monocrotophos revealed that two compounds, which exhibit anticholinesterase property, elicited similar effects. Thus, the effects raised question whether the adrenal and glycemic effects are mediated through the anticholinesterase property of OPI. To address the question, we studied the extent of AChE inhibition elicited by monocrotophos at 2 and $4 \mathrm{~h}$ 
after administration. Influence of cholinergic antagonists was investigated at $2 \mathrm{~h}$ after administration on stressogenic (hypercorticosteronemia and induction of liver TAT activity) and hyperglycemic potential of monocrotophos. For the purpose of mechanistic investigations, we employed two muscarinic cholinergic antagonists- atropine sulphate, a general ACh receptor antagonist that can pass through blood brain barrier (BBB) (Guarini et al., 2004) and methyl atropine nitrate, which is a peripherally active antagonist that does not pass through blood BBB (Pavlov et al., 2006). Both antagonists were administered at $30 \mu \mathrm{mols} / \mathrm{kg}$ b.w 3-5 min before monocrotophos (1/10 LD50).

Monocrotophos elicited significant inhibition of AChE activity ( $>50 \%)$ in brain, adrenals and liver at both 2 and $4 \mathrm{~h}$ after exposure (Fig. 5A). Of the organs studied, maximum inhibition of AChE activity was evident in brain ( 84 and $78 \%$ at 2 and $4 \mathrm{~h}$ respectively) while the enzyme activity in adrenals was inhibited to 32 and $34 \%$ of control activity at 2 and $4 \mathrm{~h}$ after exposure respectively. Similarly, monocrotophos administration reduced liver AChE activities to 47 and $46 \%$ of control at 2 and $4 \mathrm{~h}$ after exposure respectively. More importantly, we did not observe any spontaneous reactivation of inhibited AChE activity at 4h after administration, which is an important feature of the enzymes' behavior (Reiner and Aldridge, 1967; Reiner, 1971). This indicates that, while hyperglycemic potential of monocrotophos in rats may be a result of its anticholinesterase potency, the reversibility of hyperglycemia is not a consequence of spontaneous reactivation of the enzyme. Reversibility of hyperglycemia may hence be a consequence of counter-regulatory mechanism as reflected by glycogen deposition at $4 \mathrm{~h}$ after administration. Increase in glycogen content upon $4 \mathrm{~h}$ exposure is a clear indication of mobilization of glucose into glycogen synthesis pathway as a measure to overcome hyperglycemia.

We also observed that both cholinergic antagonists were potent in offering protection against stressogenic and hyperglycemic potential of monocrotophos. Administration of monocrotophos elicited significant hyperglycemia (103\%) (Fig. 5B). Pre- treatment of rats with atropine sulfate (106.04 \pm 1.83 compared to $191.82 \pm 7.59 \mathrm{mg} / \mathrm{dl}$ of monocrotophos alone) and atropine methyl nitrate (123.49 \pm 4.12 compared to $191.82 \pm 7.59 \mathrm{mg} / \mathrm{dl}$ of monocrotophos alone) offered significant protection against hyperglycemia induced by monocrotophos. It has been earlier demonstrated that diazinon-induced hyperglycemia was mediated by AChE inhibition, as revealed by protective effects of pralidoxime (AChE reactivator) (Seifert, 2001). Monocrotophos-induced hypercorticosteronemia (112\%) was effectively prevented by cholinergic antagonists (Fig. 5C). Pre-treatment of rats with atropine sulfate (33.98 \pm 2.89 compared to $76.63 \pm 1.76 \mu \mathrm{g} / \mathrm{dl}$ of monocrotophos alone) and atropine methyl nitrate (44.67 \pm 1.64 compared to $76.63 \pm 1.76 \mu \mathrm{g} / \mathrm{dl}$ of monocrotophos alone) offered significant protection against hypercorticosteronemia induced by monocrotophos. Monocrotophos induced a marked increase in the TAT activity in liver $(107 \%)$ (Fig. 5D). Pre-treatment of rats with atropine sulfate $(20.42 \pm 1.70$ compared to $33.38 \pm 1.09 \mathrm{nmol} / \mathrm{min} / \mathrm{mg}$ protein) and atropine methyl nitrate (22.39 \pm 0.79 compared to $33.38 \pm 1.09 \mathrm{nmol} / \mathrm{min} / \mathrm{mg}$ protein) offered significant protection against induction of TAT activity. These results clearly indicated that both physiological stress (hypercorticosteronemia and induction of liver TAT activity) and hyperglycemia manifest as a consequence of peripheral muscarinic cholinergic stimulation. Corticosterone exerts hyperglycemic action by up-regulation of gluconeogenesis machinery. Hence, hypercorticosteronemia and induction of liver TAT (gluconeogenesis enzyme) activity accompanying hyperglycemia raises a question whether hypercorticosteronemia is responsible hyperglycemia in monocrotophos-treated rats. 


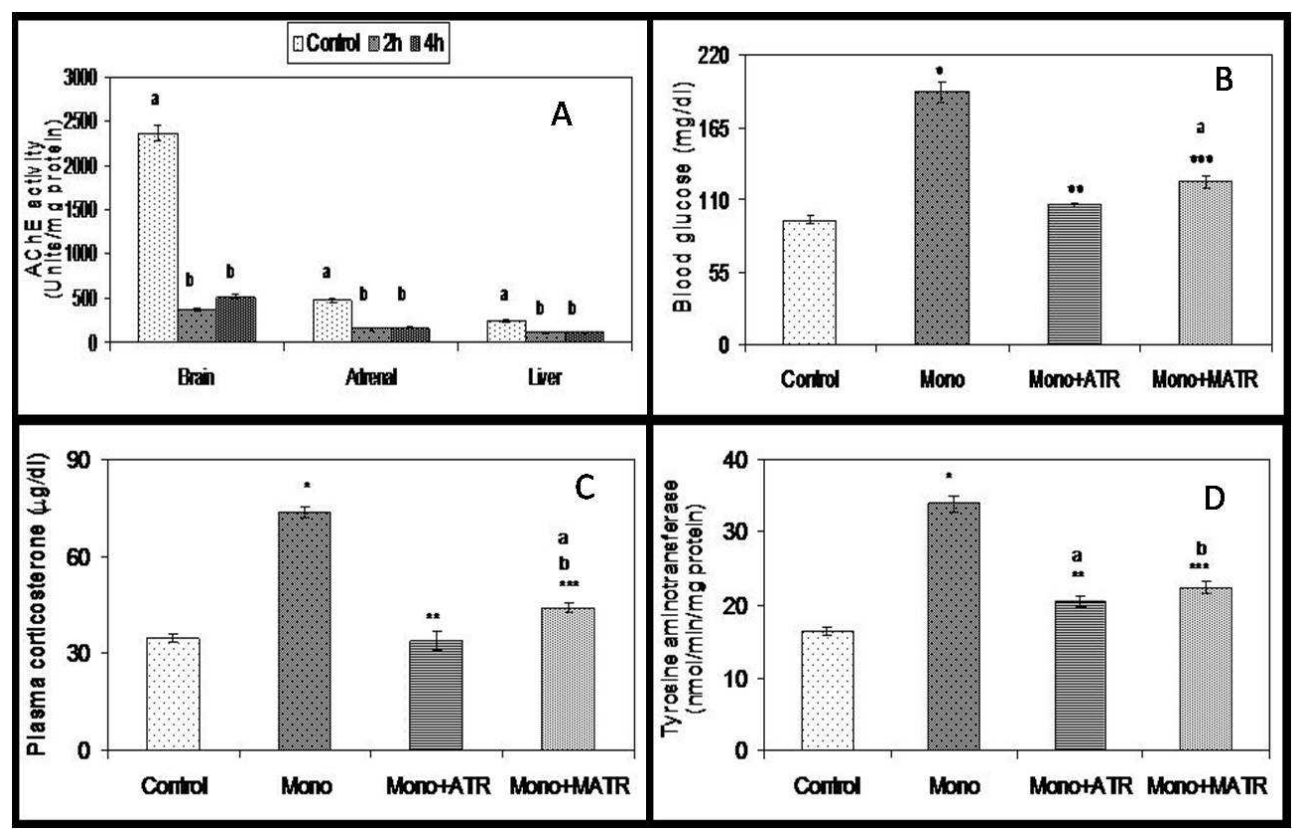

Fig. 5. Protective effects of atropine (ATR) and methyl atropine (MATR) against stressogenic and hyperglycemic potential of monocrotophos (Mono) (Joshi and Rajini, 2010).

Acetylcholine exerts strong influence on functioning of hypothalamus-pituitary-adrenal (HPA) axis. Acetylcholine has been found to increase corticotrophin releasing hormone (CRH) activity of hypothalamus in vitro as measured by effect on corticosteroidogenesis, an effect that was antagonized by atropine (Bradbury et al., 1974). ACh has also been shown to increase secretion of immunoreactive CRH from hypothalamus in vitro (Calogero et al., 1988), an effect that was antagonized by ACh receptor antagonists, atropine (muscarinic) and hexamethonium (nicotinic). Given the importance of ACh in excitation of HPA axis, assessment of cholinergic stress in activation of HPA axis in monocrotophos treated rats becomes important. The importance of $\mathrm{ACh}$ in functioning of HPA axis is further exemplified by the fact that muscarinic receptor agonists such as carbachol (Bugajski et al., 2002) and arecoline (Calogero et al., 1989) were found to increase ACTH and corticosterone in vivo. More importantly, the agonist induced increase in ACTH and corticosterone was antagonized by atropine (Bugajski et al., 2002), suggesting role for muscarinic ACh receptor in regulation of HPA axis. Role of anticholinesterase properties of organophosphate compounds in activation of HPA axis is demonstrated by studies showing elimination of stressogenic activity of cyclohexyl methyl phosphonofluoridate (as measured by plasma corticosterone and liver tyrosine aminotransferase activity) by HI-6, a cholinesterase reactivator that sufficiently reactivated inhibited AChE in brain and diaphragm (Kassa \& Bajgar, 1995) and protection offered by atropine against diisopropylfluorophosphate induced increase in corticosterone levels (Smallridge et al., 1991). These studies clearly show the influence of $\mathrm{ACh}$ and involvement of muscarinic receptors in functioning of HPA axis. From our data on influence of cholinergic antagonists on stressogenic and hyperglycemic potential of monocrotophos, it could be hypothesized that muscarinic cholinergic stress 
triggers hypercorticosteronemia, which may lead to induction of liver gluconeogenesis and hyperglycemia. However, experiments conducted with glucocorticoid receptor and adrenergic receptor antagonists revealed that hyperglycemia in mediated by adrenergic mechanisms while hypercorticosteronemia leads to only induction of liver TAT activity (data not shown). Further, we observed that monocrotophos-induced hyperglycemia was completely abolished by a gluconeogenesis inhibitor (data not shown). This establishes that physiological stress and hyperglycemia manifest in monocrotophos treated rats as independent consequence of peripheral cholinergic stress.

We further compared the effects of monocrotophos on adrenal functions and glycemic control in rats following single and repeated doses. Comparison was made between the effects of a single dose (measured $2 \mathrm{~h}$ after administration) and that of 5 or 10 doses (one dose per day, measured $2 \mathrm{~h}$ after last dose). In both cases, the oral dose of $1.8 \mathrm{mg} / \mathrm{kg} \mathrm{b.w}$. was employed for the purpose of comparison. Interestingly, we observed that effects single dose of monocrotophos on adrenal functions and glycemic control was more severe than that of repeated doses. Single dose of monocrotophos elicited hypercorticosteronemia (114\%) with concomitant decrease in adrenal cholesterol (33\%). These adrenal effects of single dose were accompanied with hyperglycemia $(109 \%)$ and induction of liver tyrosine aminotransferase activity (113\%). However, repeated administration of monocrotophos for 5 or 10days resulted in blunting of responses. In case of repeated exposure, increase in corticosterone was 76 and $67 \%$ respectively in 5 and 10d exposure groups with 18 and 13\% decrease in adrenal cholesterol. Similarly repeated administration elicited marginal increase in blood glucose (39 and 32\%) and induction of liver TAT activity (56 and 61\%) (Fig. 6).
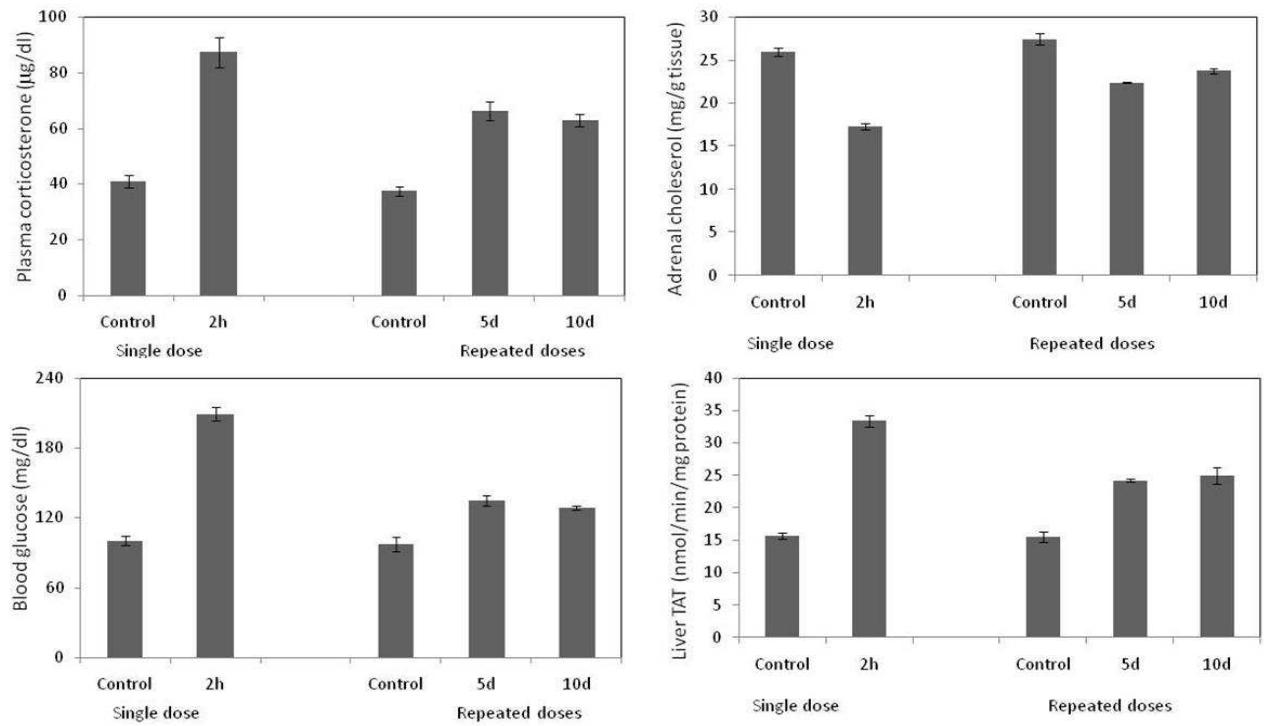

Fig. 6. Adrenal and glycemic effects of monocrotophos.

The above data clearly shows that repeated administration results in blunting of responses. This indicates that multiple administrations are associated with onset of some sort of resistance to the action of OPI. Development of tolerance to cholinesterase inhibitors during 
multiple administrations is a well documented phenomenon (Brodeur and DuBois, 1964; McPhillips, 1969; Sterri et al., 1980). Tolerance to the elevation of plasma corticosterone by DFP was reported to develop during repeated administration (Kokka et al., 1985). Several studies suggest that cholinergic receptors could be involved in onset of tolerance to OPI, which may be mediated by events such as down regulation of muscarinic receptors (Costa et al., 1982a\&b). Tolerance to the toxic effects of dilsulfoton during multiple exposures has been attributed to reduced muscarinic receptor binding in tissues of rats tolerant to the insecticide (Schwab et al., 1981). Blunted responses observed by us in case of repeated administration of monocrotophos may be attributed to tolerance mechanisms such as down regulation of muscarinic receptors. One mechanism that may be responsible for development of resistance is increased blood insulin levels. Comparison of effects of acute and repeated doses of monocrotophos on plasma insulin levels, however, needs to be done. Such a hyperinsulinemic response has been reported in case of exposure to malathion. While malathion caused increase in blood glucose and insulin levels after single exposure and continued dietary administration for 4 weeks, the degree of hyperinsulinemia was markedly greater in dietary group (Panahi et al., 2006). Thus, repeated administration of organophosphorus insecticides leads to blunting of responses. Although blunted, these responses still represent a great threat to euglycemic balance. This is particularly true in the case of constant state of hypercorticosteronemia. This has propensity to affect skeletal muscle glucose metabolism and long-term impairments in such mechanisms may lead to long lasting dysregulation in glucose homeostasis.

\subsection{OPI act as pre-disposing factors for onset of diabetes?}

Based on our comprehensive studies described above, we have proposed a scheme on the mechanism/s through which OPI might regulate/ disrupt glucose homeostasis (Fig. 7). Oxidative stress in pancreatic milieu and glucose intolerance, up regulated gluconeogenesis machinery and hyperglycemia are critical factors in diabetes etiology. With the ability to induce the above-mentioned dysregulations, OPI may have far reaching consequences on diabetic outcomes. This may be a more pertinent issue in the present times since diabetes is fast emerging as a major wide spread disorder that threatens human life. With this realization, our laboratory has also committed to investigate if OPI act as predisposing/aggravating factors for onset or progression of diabetic condition.

We observed that dichlorvos (DDVP) treated rats showed higher $(22 \%)$ levels of blood glucose compared to normal control rats while as expected, rats injected with the diabetogenic agent, Streptozotocin (STZ) alone also showed elevated (37\%) level of blood glucose. However, blood glucose levels of DDVP pre-treated rats administered STZ showed relatively higher blood glucose level compared to all the groups. Liver glycogen levels were significantly lower in rats administered either DDVP $(18 \%)$ or STZ $(19 \%)$ alone while, rats administered DDVP followed by STZ revealed further lower levels of glycogen (46 \%) (Table 5). Further, we also observed that DDVP pre-treatment resulted in more sever oxidative stress in STZ treated rats. ROS levels were significantly elevated in STZ $(40 \%)$ and DDVP (55\%) groups compared to 'untreated control' group. However, ROS levels were markedly higher (81.23 $\pm 6.52 \mathrm{pmole} \mathrm{DCF} / \mathrm{min} / \mathrm{mg}$ protein) in 'DDVP+STZ' group of rats. Pancreas of rats administered with either DDVP or STZ alone showed marginally higher levels of the lipid peroxides compared to that in 'untreated controls' while, the levels of lipid peroxides generated in pancreas of 'DDVP+STZ' rats showed 
significant increase $(110 \%)$ compared to all other groups. Pancreatic reduced glutathione level in 'DDVP+STZ' rats was significantly lower (37\%) while, rats administered with DDVP or STZ alone also had significantly lower levels of GSH, although to a lesser extent (Table 6). These results clearly demonstrate that OPI act as pre-disposing factor for diabetes as reflected by higher degree of glucotoxicity of STZ (subdiabetogenic dose) in DDVP treated rats.

\section{Organophosphorus Insecticides}

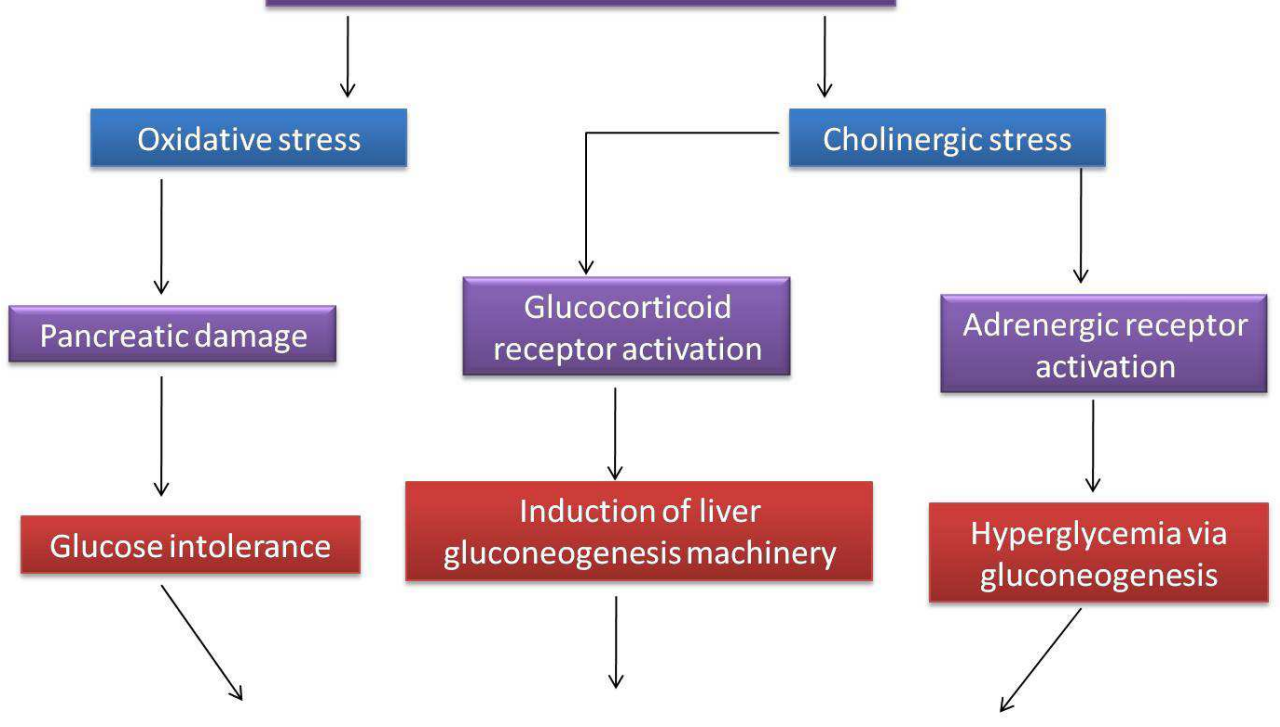

\section{Are OPI risk factors for diabetes?}

Fig. 7. Proposed scheme for OPI-induced alterations in glucose homeostasis.

Generally, an acute intraperitoneal dose of $40-60 \mathrm{mg} / \mathrm{kg}$ b.w is employed to induce significant hyperglycemia in rats. For the present study, we employed a lower dose of 25 $\mathrm{mg} / \mathrm{kg}$ b.w ('sub-diabetogenic dose') in order to examine if pre-treatment with DDVP renders these rats more susceptible to hyperglycemia. Experimental regime began with two groups with 12 rats each-control and DDVP-treated group. The DDVP-treated group animals were orally administered daily DDVP at $20 \mathrm{mg} / \mathrm{kg}$ b.w $/ \mathrm{d}$ (corresponding to $1 / 5$ of LD50 value: $100 \mathrm{mg} / \mathrm{kg} \mathrm{b.w}$, determined in a preliminary study) for $10 \mathrm{~d}$. After 10 days, rats of the control group were further divided into two sub groups of six animals each ; the first sub group served as control ('untreated control'), while the second sub group of rats was intraperitoneally injected streptozotocin (STZ, $25 \mathrm{mg} / \mathrm{kg}$ b.w.) ('STZ'). The group of rats administered with DDVP was also divided into two sub groups; the first sub group of rats served as DDVP control ('DDVP'), while the second sub group of rats was injected with streptozotocin (i.p, 25mg/kg b.w.) ('DDVP+STZ'). 


\begin{tabular}{ccc}
\hline Group & Blood glucose $^{1}$ & Liver glycogen $^{2}$ \\
\hline CONTROL & $113.53^{\mathrm{a}} \pm 2.31$ & $41.55^{\mathrm{c}} \pm 2.01$ \\
DDVP & $138.37^{\mathrm{b}} \pm 4.17$ & $34.20^{\mathrm{b}} \pm 1.42$ \\
STZ & $155.03^{\mathrm{c}} \pm 5.09$ & $33.34^{\mathrm{b}} \pm 2.23$ \\
DDVP+STZ & $188.99 \mathrm{~d} \pm 4.44$ & $22.62^{\mathrm{a}} \pm 3.52$ \\
\hline
\end{tabular}

${ }^{1} \mathrm{mg} / \mathrm{dl} ;{ }^{2} \mathrm{mg} / \mathrm{g}$ tissue; Values are mean \pm SEM $(\mathrm{n}=6)$; Mean in the same column with different superscript differ significantly $(p<0.05)$

Table 5. Blood glucose and liver glycogen levels in rats treated with DDVP \pm STZ (i.p , 25 $\mathrm{mg} / \mathrm{kg} \mathrm{b.w).}$

\begin{tabular}{cccc}
\hline Group & ROS $^{1}$ & TBARS $^{2}$ & GSH $^{3}$ \\
\hline Untreated control & $38.76^{\mathrm{a}} \pm 4.04$ & $242.76^{\mathrm{a}} \pm 19.18$ & $1.07^{\mathrm{c}} \pm 0.03$ \\
DDVP & $60.18^{\mathrm{b}} \pm 4.59$ & $294.94^{\mathrm{a}} \pm 10.65$ & $0.83^{\mathrm{b}} \pm 0.01$ \\
STZ & $54.27^{\mathrm{b}} \pm 2.89$ & $283.63^{\mathrm{a}} \pm 7.27$ & $0.78^{\mathrm{b}} \pm 0.02$ \\
DDVP+STZ & $81.23^{\mathrm{c}} \pm 6.52$ & $389.38^{\mathrm{b}} \pm 38.47$ & $0.67^{\mathrm{a}} \pm 0.02$ \\
\hline
\end{tabular}

${ }^{1} \mathrm{pmol} \mathrm{DCF} / \mathrm{min} / \mathrm{mg}$ protein; ${ }^{2} \mathrm{nmol} / \mathrm{g}$ tissue; ${ }^{3} \mathrm{mg} / \mathrm{g}$ tissue

Values are mean \pm SEM $(n=6)$; Mean in the same column with different superscript differ significantly $(p<0.05)$

Table 6. Oxidative stress parameters in pancreas of rats treated with DDVP \pm STZ (i.p , 25 $\mathrm{mg} / \mathrm{kg} \mathrm{b.w).}$

\subsection{Do OPI aggravate diabetic outcomes?}

To address this question, we investigated the diabetic outcomes in rats experimentally rendered diabetic and post-treated with monocrotophos. Rats were rendered diabetic with an acute dose $(60 \mathrm{mg} / \mathrm{kg}$ b.w, i.p) of streptozotocin. Monocrotophos was orally administered at a sublethal dose $\left(1 / 20 \mathrm{LD}_{50}, 0.9 \mathrm{mg} / \mathrm{kg}\right.$ b.w./ d, 5 days $)$ to both normal and diabetic rats. We observed that monocrotophos per se moderately increased (25\%) the blood glucose levels in normal rats, but significantly aggravated the hyperglycemic outcome in diabetic rats (56\% above diabetic rats). We observed the typical lipid profile alterations among diabetic rats characterized by increase in total cholesterol and triglycerides (TG) in serum. While monocrotophos did not impact lipid profile per se, its interaction with diabetic component resulted in severe alterations lipid profile that reflected in phenomenal increase in serum triglyceride. Such augmented impairments may have high bearing on cardiovascular health since the cardiovascular risk index was alarmingly high among diabetic rats treated with monocrotophos (Fig. 8). Further, monocrotophos resulted in higher degree of hepatic and renal toxicity as reflected by alterations in serum transaminase activities and blood urea nitrogen values respectively (Table 7).

Further, it is now established that oxidative stress in an important consequence of diabetic condition and plays as an important pathophysiological factor in progression of diabetic complications (Maritim, 2003). We observed that STZ-induced diabetes was associated with increased lipid peroxidation (122\%), depletion of reduced glutathione $(10 \%)$ and alterations in activities of two important antioxidant enzymes (superoxide dismutase and catalase) in kidney. Monocrotophos further deteriorated oxidative impairments in kidney as evidenced by further increase in lipid peroxidation (170\%) and depletion of reduced glutathione $(18 \%)$ content. Diabetes was associated with marginal decrease in superoxide dismutase activity in kidney, which was further reduced by monocrotophos treatment (35\%) (Fig. 9). 


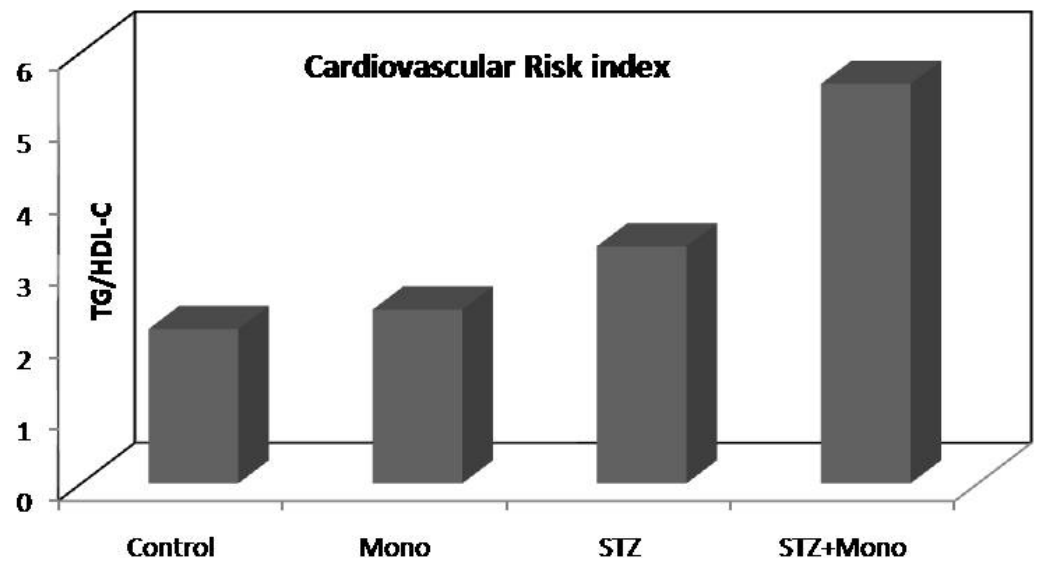

Fig. 8. Effect of repeated oral doses of monocrotophos at $1 / 20 \mathrm{LD}_{50}(0.9 \mathrm{mg} / \mathrm{kg} \mathrm{b.w})$ on cardiovascular index in control and diabetic rats (Begum and Rajini, 2011a).

\begin{tabular}{ccccc}
\hline & Control & Mono & STZ & STZ+Mono \\
\hline Blood glucose & $101.58 \pm$ & $126.91 \pm$ & $382.71 \pm$ & $597.94 \pm$ \\
(mg/dl) & 1.4 & 8.9 & $14.0^{\mathrm{ab}}$ & $12.5^{\mathrm{cde}}$ \\
TC & $38.00 \pm$ & $41.92 \pm$ & $50.45 \pm$ & $50.42 \pm$ \\
$(\mathrm{mg} / \mathrm{dl})$ & 2.1 & 1.9 & $1.6^{\mathrm{a}}$ & $1.2^{\mathrm{a}}$ \\
$\mathrm{HDL}-\mathrm{C}$ & $31.09 \pm$ & $32.68 \pm$ & $37.84 \pm$ & $35.48 \pm$ \\
$(\mathrm{mg} / \mathrm{dl})$ & 1.2 & 1.7 & 1.4 & 1.3 \\
TG & $66.74 \pm$ & $78.12 \pm$ & $125.44 \pm$ & $193.52 \pm$ \\
$(\mathrm{mg} / \mathrm{dl})$ & 3.5 & 6.9 & $9.2^{\mathrm{a}}$ & $19.4 \mathrm{bcd}$ \\
BUN & $33.08 \pm$ & $51.88 \pm$ & $71.18 \pm$ & $78.05 \pm$ \\
$(\mathrm{mg} / \mathrm{dl})$ & 5.6 & 8.2 & $10.1^{\mathrm{a}}$ & $5.2^{\mathrm{b}}$ \\
SC & $0.63 \pm$ & $0.72 \pm$ & $0.81 \pm$ & $0.84 \pm$ \\
$(\mathrm{mg} / \mathrm{dl})$ & 0.06 & 0.1 & 0.1 & 0.04 \\
Serum ALT & $66.19 \pm$ & $72.24 \pm$ & $80.03 \pm$ & $120.77 \pm$ \\
$(\mathrm{U} / \mathrm{L})$ & 2.0 & 0.7 & 2.4 & $9.2^{\mathrm{abc}}$ \\
Serum AST & $126.57 \pm$ & $156.00 \pm$ & $199.78 \pm$ & $341.55 \pm$ \\
$(\mathrm{U} / \mathrm{L})$ & 0.2 & 18.7 & $14.2^{\mathrm{de}}$ & $8.5^{\mathrm{abc}}$ \\
\hline
\end{tabular}

(Begum and Rajini, 2011a)

Data analyzed by Tukey's HSD test; Mean \pm SEM $(n=4)$

TC: Total cholesterol; HDL-C: High-density lipoprotein ; TG: Triglyceride; BUN: Blood Urea Nitrogen; SC: Serum creatinine

Table 7. Effect of repeated oral doses of monocrotophos at $1 / 20 \mathrm{LD}_{50}(0.9 \mathrm{mg} / \mathrm{kg} \mathrm{b.w})$ on blood glucose, lipid profile and hepatic and renal damage markers in serum in control and diabetic rat.

Our work on interaction of OPI with diabetic component clearly shows that OPI can act as both predisposing and aggravating factors for diabetes. The inference becomes an important consideration to be made as the modern world is facing an escalating situation of alarming increase in the incidence of diabetes. Our study employed a low dose of monocrotophos, 
which per se did not interfere with lipid profile in rats, yet causing augmentation of alteration in lipid profile in diabetic rats. However, other studies have clearly demonstrated that several OPI cause alterations in lipid profile, particularly hypertriglyceridemia (Ryhänen et al, 1984; Ibrahim \& El-Gamal, 2003; Rezg et al., 2010). Dyslipidemia or lipid abnormalities play an important role in the progression of diabetes (Goldberg, 2001) and these are characterized by lipid derangements including hypertriglyceridemia, low highdensity cholesterol (HDL-C), and a high concentration of small dense low-density lipoprotein (LDL) particles. Further, a state of elevated hypertriglyceridemia is commonly associated with insulin resistance and represents a valuable clinical marker of the metabolic syndrome (Grundy et al., 1999). Propensity of OPI to induce hypertriglyceridemia coupled with their permissive effects of gluconeogenesis in liver creates a serious threat to glucose homeostasis.
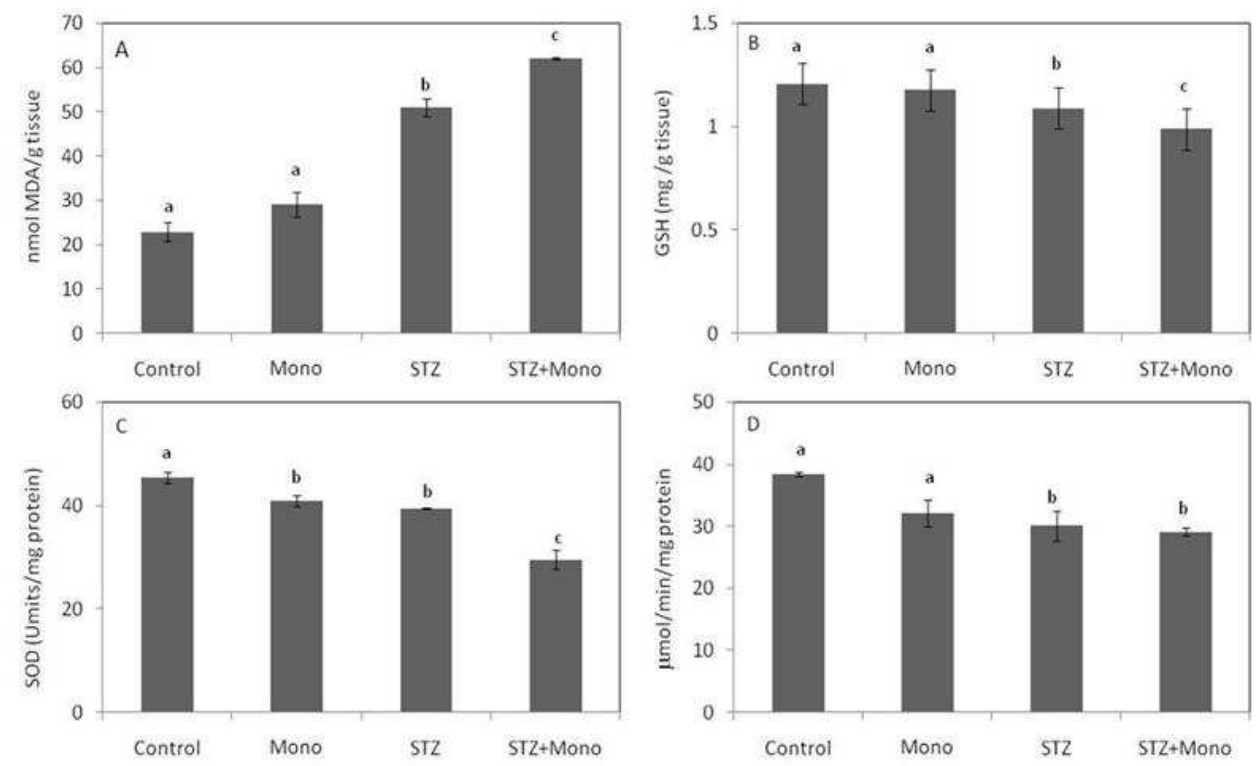

Fig. 9. Effect of repeated oral doses of monocrotophos at $1 / 20 \mathrm{LD}_{50}(0.9 \mathrm{mg} / \mathrm{kg} \mathrm{b.w})$ on oxidative balance in kidney of control and diabetic rats (Begum and Rajini, 2011b).

\section{Conclusion}

Given the status of OPI as environmental pollutant with residues being detected in biosphere around, which are now being shown to make it into human body, it is almost certain that OPI will interact with etiological factors of diabetes at toxicologically significant levels. Interaction of living system with OPI may have severe two-way impact on glycemic control. As documented facilitators of hepatic glucose output via glycogenolysis and gluconeogenesis, OPI are most likely to elicit hyperglycaemic responses in humans during exposure. Further, OPI may also affect the responsiveness to human system to insulin via 
multiple mechanisms, causing predisposition to diabetes. From our studies, it is also clear that OPI may also act to augment diabetic outcomes. In most societies, large sections of populations are subject to diabetes risk factors such as unhealthy diet patterns, lack of physical exercise and obesity. With such high odds of risk factors, the burden of constant exposure to OPI (as environmental pollutants) could be a silent aggravating factor that is causing increase in incidence of diabetes.

\section{Acknowledgments}

The authors we wish to thank the Director, CFTRI for extending support for this research. Indian Council of Medical Research (New Delhi) is gratefully acknowledged for funding the research programme described herein. The first author (AKRJ) thanks the Council of Industrial and Scientific Research (New Delhi) for award of Research Fellowship.

\section{References}

Abdollahi, M., Donyavi, M., Pournourmohammadi, S., \& Saadat M. (2004a). Hyperglycemia associated with increased hepatic glycogen phosphorylase and phosphoenol pyruvate carboxykinase in rats following sub-chronic exposure to malathion. Comparative Biochemistry \& Physiology (C), 137, 343-347.

Abdollahi, M., Ranjbar, A., Shadnia, S., et al. (2004b). Pesticides and oxidative stress; review. Medical Science Monitor, 10, 141-147.

Abou-Donia, M. (2003). Organophosphorus Ester-Induced Chronic Neurotoxicity. Archives of Environmental Health, 58, 484-497.

Akhgari, M., Abdollahi, M., Kebryaeezadeh, A., et al. (2003). Biochemical evidence for free radical-induced lipid peroxidation as a mechanism for sub chronic toxicity of malathion in blood and liver of rats. Human \& Experimental Toxicology, 22, 205-211.

Andrews, RC., \& Walker, BR. (1999). Glucocorticoids and insulin resistance: old hormones, new targets. Clinical Science, 96, 513-523.

Argaud. D., Zhang, Q., Malatra, S., et al. (1996). Regulation of rat liver glucose-6phosphatase gene expression in different nutritional and hormonal states. Diabetes, 45, 1563-1571.

Banerjee, BD., Seth, V., \& Ahmed, RS. (2001). Pesticide-induced oxidative stress: perspective and trends. Reviews on Environmental Health, 16, 1-40.

Begum, K, \& Rajini, PS. (2011a). Monocrotophos augments the early alterations in lipid profile and organ toxicity associated with experimental diabetes in rats. Pesticide Biochemistry \& Physiology, 99, 33-38.

Begum, K \& Rajini, PS. (2011b). Augmentation of hepatic and renal oxidative stress and disrupted glucose homeostasis by monocrotophos in streptozotocin-induced diabetic rats. Chemico Biological Interactions, (In press).

Bradbury, MWB., Burden, J., Hillhouse, EW., \& Jones, MT. (1974). Stimulation electrically and by acetylcholine of the rat hypothalamus in vitro. Journal of Physiology, 239, 269-83.

Brodeur, J., \& DuBois, KP. (1964). Studies on the mechanism of acquired tolerance by rats O, O-diethyl S-2- (ehylthio) ethyl phosphorodithioate (Di-syston). Archives of International Pharmacodynamics, 149, 560-570. 
Bugajski, J., Gadek-Michalska, A., \& Bugajski, AJ. (2002). Effect of constitutive- and inducible-cyclooxygenase in the carbachol-induced pituitary-adrenocortical response during social stress. Journal of Physiology \& Pharmacology, 53, 453-462.

Calogero AE, Kamilaris TC, Gomez MT, et al. (1989). The muscarinic cholinergic agonist arecoline stimulates the rat hypothalamic-pituitary-adrenal axis through a centrally-mediated corticotropin-releasing hormone-dependent mechanism. Endocrinology, 125, 2445-2453.

Calogero, AE., Gallucci, WT., Bernardini, R., et al. (1988). Effect of cholinergic agonists and antagonists on rat hypothalamic corticotropin-releasing hormone secretion in vitro. Neuroendocrinology. 47, 303-308.

Costa, LG., Schwab, BW., \& Murphy, SD. (1982a). Differential alterations of cholinergic muscarinic receptors during chronic and acute tolerance to organophosphorus insecticides. Biochemical Pharmacology, 31, 3407-3413.

Costa, LG., Schwab, BW., \& Murphy, SD. (1982b). Tolerance to anticholinesterase compounds in mammals. Toxicology, 25, 79-97.

Deotare, ST., \& Chakrabarti, CH. 1981. Effect of acephate (orthene) on tissue levels of thiamine, pyruvic acid, lactic acid, glycogen and blood sugar. Indian Journal of Physiology \& Pharmacology, 25, 259-264.

Dressel, TD., Goodale, RL Jr, Zweber B, \& Borner JW. 1982. The effect of atropine and duct decompression on evolution of diazinon-induced canine pancreatitis. Annals of Surgery, 195: 424-434.

Dressel, TD., Goodale, RL Jr., Ameson, MA., \& Borner, JW. (1979). Pancreatitis as a complication of anticholinesterase insecticide intoxication. Annals of Surgery, 189, 199-204.

Eto, M. (1974). Organophosphorus Pesticides: Organic and Biological Chemistry, 387 pp, CRC Press, Cleveland, OH.

Fletcher, HP, Akbar, WJ, Peoples, RW, \& Spratto, GR. (1998). Effect of acute soman on selected endocrine parameters and blood glucose in rats. Fundamental $\mathcal{E}$ Applied Toxicology, 11, 580-586.

Frick, TW, Dalo, S, O'Leary, JF, et al. (1987). Effects of insecticide, diazinon, on pancreas of $\mathrm{dog}$, cat and guinea pig. Journal of Environmental Pathology, Toxicology and Oncology, 7, 1-11.

Fukuto, TR. (1990). Mechanism of action of organophosphorus and carbamate insecticides. Environmental Health Perspectives, 87, 245-254.

Galloway, T, \& Handy R. (2003). Immunotoxicity of organophosphorus pesticides. Ecotoxicology, 12, 345-363.

Ganss, R, Weih, F, \& Schutz G. (1994). The Cyclic Adenosine 3'5'-Monophosphate and the glucocorticoids-dependent enhancers are targets for insulin repression of tyrosine aminotransferase gene transcription. Molecular Endocrinology, 8, 895-903.

Gokalp, O, Buyukvanh, B, \& Cicek E, et al. (2005). The effects of diazinon on pancreatic damage and ameliorating role of vitamin $\mathrm{E}$ and vitamin C. Pesticide Biochemistry $\mathcal{E}$ Physiology, 81, 123-128.

Goldberg, JI. (2001). Diabetic dyslipidemia: causes and consequences. The Journal of Clinical Endocrinology \& Metabolism, 86, 965-971.

Grundy, SM. (1999). Hypertriglyceridemia, insulin resistance, and the metabolic syndrome. American Journal of Cardiology, 83, 25F-29F. 
Guarini, S, Cainizzo, MM, Giuliani, D, et al. (2004). Adrenocorticotropin reverses hemorrhagic shock in anesthetized rats through the rapid activation of a vagal antiinflammatory pathway. Cardiovascular Research, 63, 357-365.

Gupta, PK. (1974). Malathion induced biochemical changes in rats. Acta Pharmacology et. Toxicology, 35, 191-194.

Hsiao, CT, Yang, CC, Deng, JF, et al. (1996). Acute pancreatitis following organophosphate intoxication. Journal of Toxicology Clinical Toxicology, 34, 343-347.

Hudon, M, \& Clement, JG. (1986). Effect of soman (pinacolyl methylphosphonofluoridate) on the blood levels of corticosterone and adrenocorticotropin in mice. Candian Journal of Physiology \& Pharmacology, 64, 1339-1342.

Ibrahim, NA, El-Gamal, BA. (2003). Effects of diazinon, an organophosphate insecticide, on plasma lipid consitutents in experimental animals. Journal of Biochemistry and Molecular Biology, 36, 499-504.

Joshi AK, Rajini PS. 2010. Hyperglycemic and stressogenic effects of monocrotophos in rats: Evidence for the involvement of acetylcholinesterase inhibition. Experimental $\mathcal{E}$ Toxicologic Pathology, (In press).

Joshi, AK, \& Rajini, PS. (2009). Reversible hyperglycemia in rats following acute exposure to acephate, an organophosphorus insecticide: role of gluconeogenesis. Toxicology, $257,40-45$

Kamath, V, Joshi, AKR, \& Rajini, PS. (2008). Dimethoate induced biochemical perturbations in rat pancreas and its attenuation by cashew nut skin extract. Pesticide Biochemistry $\mathcal{E}$ Physiology, 90, 58-65.

Kamath, V, Rajini, PS. (2007). Altered glucose homeostasis and oxidative impairment in pancreas of rats subjected to dimethoate intoxication. Toxicology. 231, 137-146.

Kassa, J, \& Bajgar, J. (1995). Comparison of the efficacy of HI-6 and obidoxime against cyclohexyl methyl phosphonofluoridate (GF) in rats. Human $\mathcal{E}$ Experimental Toxicology, 11, 923-928.

Kassa, J. (1995). Comparison of efficacy of two oximes (HI-6 and obidoxime) in soman poisoning in rats. Toxicology, 101, 167-174.

Kassa, J. (1997). Importance of cholinolytic drug selection for the efficacy of HI-6 against soman in rats. Toxicology, 116, 147-152.

Kokka, N, Lee, R, \& Lomax P. (1985). Effects of organophosphae cholinesterase inhibitors on pituitary adrenal activity and thermoregulation. In Fifth Annual Chemical Defense Bioscience Review. 60.

Koundinya, PR, Ramamurthi, R. (1979). Effect of organophosphate pesticide (fenitrothion) on some aspects of carbohydrate metabolism in a freshwater fish, Saotherodon (Tilapia) mossamicus (Peters). Experientia, 35, 1632-1633.

Kuz'minskaia, UA, Bersan, LV, \& Veremenko, LM. (1978). Activity of the indicator enzymes of liver subcellular structures with the prolonged administration of Valexon. Vopr. Pitan, 5, 48-51.

Lasram, MM, Annabi, AB, Rezg R, et al. (2008). Effect of short-time Malathion administration on glucose homeostasis in Wistar rat. Pesticide Biochemistry $\mathcal{E}$ Physiology, 92, 114-119.

Maritim, AC, Sanders, RA, Watkins (III), JB. (2003). Diabetes, Oxidative Stress, and Antioxidants: A Review. Journal of Biochemical \& Molecular Toxicology, 17, 24-38. 
Marsh, WH, Viekov, GA, \& Conradi, EC. (1988). Acute pancreatitis after cutaneous exposure to an organophosphate insecticide. American Journal of Gastroenterology, 83, 11581160.

Mathur HB, Johnson S, Mishra R., et al. (2003). Analysis of pesticide residues in bottled water (Delhi Region). CSE Report. http://www.cseindia.org/userfiles/Delhi_uploadfinal_sn.pdf

Mathur, HB, Agarwal, HC, Johnson, S, \& Saikia, N. (2005). Analysis Of Pesticide Residues In Blood Samples From Villages Of Punjab. CSE Report. http://www.cseindia.org/userfiles/Punjab_blood_report.pdf

Matin, MA, Khan, SN, Hussain K, \& Sattar S. 1989. Effects of adrenalectomy on diazinoninduced changes in carbohydrate metabolism. Archives of Toxicology, 63, 376-380.

McPhillips, JJ. (1969). Altered sensitivity to drugs following repeated injections of a cholinesterase inhibitor to rats. Toxicology and Applied Pharmacology, 14, 67-73.

Meller, D, Fraser, I, \& Kryger, M. (1981). Hyperglycemia in anticholinesterase poisoning. Candian Medical Association Journal, 124, 745-748.

Mollaoglu, H, Yilmaz, HR, Gokalp, O, \& Altuntas I. (2003). Methidathion un pankreas uzerine erkileri: Vitamin E ve C nin rolu. Van Tip Dergisi, 10, 98-100.

Moore, PG, \& James, OF. (1988). Acute pancreatitis induced by acute organophosphate poisoning. Postgraduate Medical Journal, 57, 660-662.

Namba, T. (1971). Cholinesterase inhibition by organophosphorus compounds and its clinical effects. Bulletin - World Health Organization, 44, 289-307.

O'Brien, RM, Lucas, PC, Forest CD, et al. (1990). Identification of a sequence in the PEPCK gene that mediates a negative effect of insulin on transcription. Science. 249, 533537.

Osicka-Kaprowska, A, Lipska M, Wysocka-Paruzewska, B. (1984). Effect of chlorfenvinphos on plasma corticosterone and aldosterone levels in rats. Archives of Toxicolicology, $55,68-69$.

Panahi,P, Vosough-Ghanbari, S, Pournourmohammadi, S, et al. (2006). Stimulatory Effects of Malathion on the Key Enzymes Activities of Insulin Secretion in Langerhans Islets, Glutamate Dehydrogenase and Glucokinase. Toxicology Mechanisms $\mathcal{E}$ Methods, 16, 161-167.

Pavlov, VA, Ochani M, Gallowitsch-Puetra, M, et al. (2006). Central muscarinic cholinergic regulation of the systemic inflammatory response during endotoxemia. Proceedings of the National Academy of Sciences, USA, 103, 5219-5223.

Pilkis, SJ, \& Granner, DK. (1992). Molecular physiology of the regulation of hepatic gluconeogenesis and glycolysis. Annual Review of Physiology, 54, 885-909.

Rahimi, R, \& Abdollahi, M. (2007). A review on the mechanisms involved in hyperglycemia induced by organophosphorus pesticides. Pesticide Biochemistry \& Physiology, , 115121.

Ranjbar, A, Pasalar, P, \& Abdollahi, M. (2002). Induction of oxidative stress and acetylcholinesterase inhibition in organophosphorous pesticide manufacturing workers. Human \& Experimental Toxicology, 21, 179-182.

Reiner, E, \& Aldridge, WN. (1967). Effect of pH on inhibition and spontaneous reactivation of acetylcholinesterase treated with esters of phosphorus acids and carbamic acids. Biochemical Journal, 105: 171-179. 
Reiner, E. (1971). Spontaneous reactivation of phosphorylated and carbamylated cholinesterase. Bulletin of World Health Organization, 44, 109-112.

Rezg, R, Mornagui, B, Benahmed, M, etal. (2010). Malathion exposure modulates hypothalamic gene expression and induces dyslipedemia in Wistar rats. Food $\mathcal{E}$ Chemical Toxicology. 48, 1473-1477.

Rodrigues, MA, Puga, FR, Chenker, E, \& Mazanti, MT. (1986). Short-term effect of malathion on rats' blood glucose and on glucose utilization by mammalian cells in vitro. Ecotoxicology \& Environnemental Safety, 12 , 110-113.

Ryhänen, R, Herranen, J, Korhonen, K, et al. (1984). Relationship between serum lipids, lipoproteins and pseudocholinesterase during organophosphate poisoning in rabbits. International Journal Biochemistry. 16: 687-690.

Sanghi, R, Pillai, MK, Jayalekshmi, TR, \& Nair A. (2003). Organochlorine and organophosphorus pesticide residues in breast milk from Bhopal, Madhya Pradesh, India. Human \& Experimental Toxicology. 22, 73-6.

Schwab, BW, Hand, H, Costa, LG, \& Murphy, SD. (1981). Reduced muscarinic receptor binding in tissues of rats tolerant to the insecticide disulfoton. Neurotoxicology. 2, 635-47.

Seifert, J. (2001). Toxicological significance of the hyperglycemia caused by organophosphorous insecticides. Bulletin of Environmental Contamination \& Toxicology, 67, 463-469.

Sevillano, S, de la Mano, AM, Manso, MA, et al. (2003). N-acetylcysteine prevents intraacinar oxygen free radical production in pancreatic duct obstruction-induced acute pancreatitis. Biochimica et Biophysica Acta, 20, 177-184.

Smallridge, RC, Carrb, FE, \& Feina, HG. (1991). Diisopropylfluorophosphate (DFP) reduces serum prolactin, thyrotropin, luteinizing hormone, and growth hormone and increases adrenocorticotropin and corticosterone in rats: Involvement of dopaminergic and somatostatinergic as well as cholinergic pathways. Toxicology $\mathcal{E}$ Applied Pharmacology, 180, 284-295.

Sogorb, MA, \& Vilanova, E. (2002). Enzymes involved in detoxification of organophosphorus, carbamate and pyrethroid insecticides through hydrolysis. Toxicology Letters, 128, 215-228.

Soltaninejad, K, \& Abdollahi, M. (2009). Current opinion on the science of organophosphate pesticide and toxic stress: A systematic review. Medical Science Monitor, 15, RA75RA90.

Spassova, D, White, T, \& Singh, AK. (2000). Accute effects of acephate and methamidophos on acetylcholinesterase activity, endocrine system, and amino acid concentrations in rats. Comparative Biochemistry \& Physiology Part (C), 12, 79-89.

Sterri, SH, Lyngaas, S, \& Fonnum, F. (1980). Toxicity of soman after repetitive injection of sublethal doses in rat. Acta Pharmacology et Toxicology (Copenh). 46, 1-7.

Sultatos, LG. (1994). Mammalian toxicology of organophosphorous pesticides. Journal of Toxicology \& Environmental Health, 43, 271-289. 


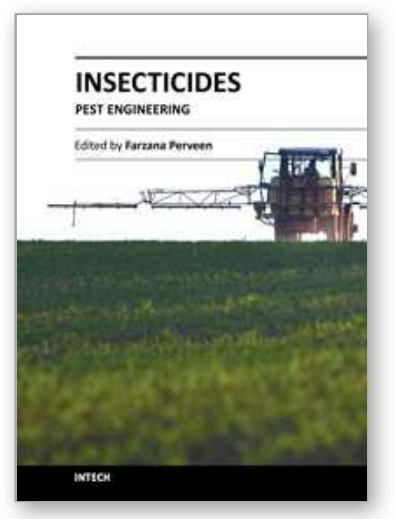

\author{
Insecticides - Pest Engineering \\ Edited by Dr. Farzana Perveen
}

ISBN 978-953-307-895-3

Hard cover, 538 pages

Publisher InTech

Published online 15, February, 2012

Published in print edition February, 2012

This book is compiled of 24 Chapters divided into 4 Sections. Section A focuses on toxicity of organic and inorganic insecticides, organophosphorus insecticides, toxicity of fenitrothion and permethrin, and dichlorodiphenyltrichloroethane (DDT). Section B is dedicated to vector control using insecticides, biological control of mosquito larvae by Bacillus thuringiensis, metabolism of pyrethroids by mosquito cytochrome P40 susceptibility status of Aedes aegypti, etc. Section $C$ describes bioactive natural products from sapindacea, management of potato pests, flower thrips, mango mealy bug, pear psylla, grapes pests, small fruit production, boll weevil and tsetse fly using insecticides. Section $D$ provides information on insecticide resistance in natural population of malaria vector, role of Anopheles gambiae P450 cytochrome, genetic toxicological profile of carbofuran and pirimicarp carbamic insecticides, etc. The subject matter in this book should attract the reader's concern to support rational decisions regarding the use of pesticides.

\title{
How to reference
}

In order to correctly reference this scholarly work, feel free to copy and paste the following:

Apurva Kumar R. Joshi and P.S. Rajini (2012). Organophosphorus Insecticides and Glucose Homeostasis, Insecticides - Pest Engineering, Dr. Farzana Perveen (Ed.), ISBN: 978-953-307-895-3, InTech, Available from: http://www.intechopen.com/books/insecticides-pest-engineering/organophosphorus-insecticides-and-glucosehomeostasis

\section{INTECH}

open science | open minds

\author{
InTech Europe \\ University Campus STeP Ri \\ Slavka Krautzeka 83/A \\ 51000 Rijeka, Croatia \\ Phone: +385 (51) 770447 \\ Fax: +385 (51) 686166 \\ www.intechopen.com
}

\author{
InTech China \\ Unit 405, Office Block, Hotel Equatorial Shanghai \\ No.65, Yan An Road (West), Shanghai, 200040, China \\ 中国上海市延安西路65号上海国际贵都大饭店办公楼 405 单元 \\ Phone: +86-21-62489820 \\ Fax: $+86-21-62489821$
}


(C) 2012 The Author(s). Licensee IntechOpen. This is an open access article distributed under the terms of the Creative Commons Attribution 3.0 License, which permits unrestricted use, distribution, and reproduction in any medium, provided the original work is properly cited. 